\title{
鼻腔内に生じた神経鞘腫の一例
}

\author{
金子富美恵篠昭男吉原 俊 雄
}

要旨 : 神経鞘腫は頭頸部領域ではしばしば見られる腫瘍であるが, 鼻副鼻腔に認めることは稀である。 我々は左鼻腔内に生じた神経鞘腫の一例を経験したので文献的考察を加え報告する。症例：48 歳, 男性。 主訴: 左鼻汁・頭痛。既往歴 : 鼻アレルギー。現病歴 : 平成 9 年より左鼻汁, 平成 12 年 2 月より左鼻出 血，4月より頭痛が出現。5月当科初診時左中鼻道にポリープ様腫瘤を認め, CT 上腫瘤は左鼻腔を占拠 し左上顎洞内側壁・鼻中隔を圧排していた。生検では炎症性肉芽であった。6月8日全身麻酔下に内視鏡 下摘出術を施行した。腫瘤表面のポリープ様粘膜を鉗除後，充実性黄白色の腫瘤を認めた。中甲介は圧 排され萎縮, 後笁骨蜂巣開放部より分泌物が見られた。術後標本の病理検査で ANTONI A 型, S-100 蛋白陽性の神経鞘腫と確定した。術後経過は良好で, 鼻汁・頭痛は改善し, 現在に至るまで再発は認め られていない。 キーワード : 鼻腔, 神経鞘腫, 内視鏡下摘出術, ANTONI A 型

\section{Summary A case of schwannoma occurring in the nasal cavity:}

Fumie Kaneko, Akio Shino, and Toshio Yoshihara. Tokyo Women's Medical University School of Medicine

Schwannomas are neurogenic neoplasms which are rarely found in the sinonasal tract, and only 77 cases have been reported in Japan. We present a case of schwannoma occurring in the left nasal cavity, review the current literature and discuss the clinical details with specific histological features.

The patient was a 48-year-old man, who complained of nasal discharge on the left side and headache. On endoscopic examination, the left nasal cavity was occupied with a polypous mass. CT scan of the paranasal sinus revealed that the tumor occupied the left nasal cavity and was pressing out the internal wall of the left maxillary sinus and nasal septum. Biopsy of this polypous mass showed it to be only an inflammatory granulation. Under general anesthesia, the tumor was completely resected by endoscopic sinus surgery (ESS). Histological examination revealed it to be schwannoma (Antoni A type). The postoperative course was good with no signs of recurrence for 6 month.

Key words : nasal cavity, schwannoma, endoscopic sinus surgery (ESS), ANTONI A type

\section{はじめに}

神経鞘腫は, schwann 細胞由来の, 限局性,
皮膜を有する良性腫瘍であり，全身の末梢神経に 出現しうる。頭頸部領域においてもしばしば見ら れる良性腫瘍であり, 特に内耳道, 頸部に発生す る例が多い。

東京女子医科大学耳鼻咽喉科
今回我々は, 鼻腔内に生じた神経鞘腫の一例を 
経験したので，文献的考察を加え報告する。様々 な組織型の腫場が発生する鼻・副鼻腔領域である が、神経鞘腫は稀少であり, 今回我々が涉猟し得 た範囲では，本邦での報告は自験例を含め 77 例 にすぎない。

\section{症例}

症例 : 48 歳, 男性。

主訴 : 頭痛・左鼻漏。

既往歴：アレルギー性畫炎，高血圧。

家族歴 : 特記すべき事項なし。

現病歴: 平成 9 年頃より, 左鼻腔から, 白色粘 稠，時に膿性の鼻漏が出現していた。平成 12 年 2 月より左鼻出血が頻繁に出現し，他院耳鼻咽喉科 を受診。左鼻内にポリープがあると指摘され，マ クロライド系抗生物質, 粘液溶解剂の内服投与が 行われていた。4月初旬より右前頭部より後頭部 にかけての頭痛が出現した。同院脳神経外科にて 頭部 CT を行ったが, 副鼻腔炎の他は異常を認め なかった。4月 17 日，頭痛が持続するため，精查・ 加療を希望し，知人の紹介にて当科を受診した。

初診時所見: 左尊腔に表面平滑, 荅白のポリー プ样腫瘤を認めた（図 1)。腫瘤は易出血性であり， 鼻内よりは粘稠な鼾漏が吸引された。右鼻腔，後 鼻孔, 耳, 咽喉頭, 頸部に異常所見は認めず，眼 球突出, 視力障害, 眼球運動障害などの眼症状も 認められなかった。

単純レントゲン写真所見（図2）: 左篩骨洞を中 心とした腫瘤様陰影を認めた。

副鼻腔 CT 所見 (図 3): 左鼻腔に, 不均一に造 影される比較的辺縁鮮明な腫瘤が認められ, 左上 顎洞内側・悬中隔を圧排していた。明らかな骨破 壊は認められなかった。後篩骨蜂巣に液貯留像を 認めた。西側上顎洞，右篩骨洞，および蝶形骨洞 には異常陰影を認めなかった。

経過： 5 月 2 日, 腫瘤の局麻下生検を行ったが, 結果は好中球・リンパ球の浸潤を伴う浮腫状の炎 症性肉芽で，明らかな腫瘍性病変は認められなかっ た。

手術所見: 平成 12 年 6 月 8 日, 全身麻酔下内 視鏡下に鼻腔腫瘤摘出術を行った。腫瘤は総鼻道 に存在していた。中甲介は腫瘤により中鼻道側に 圧排されていた。腫瘤の基部は上鼻道に存在した。

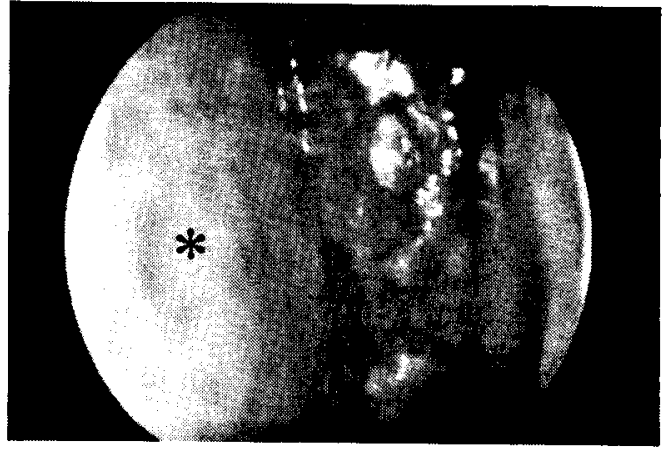

図 1 左鼾内所見

左尊䏶には表面平滑，荟白のポリープ様腫瘤を認 める(*は鼾中隔を示す)

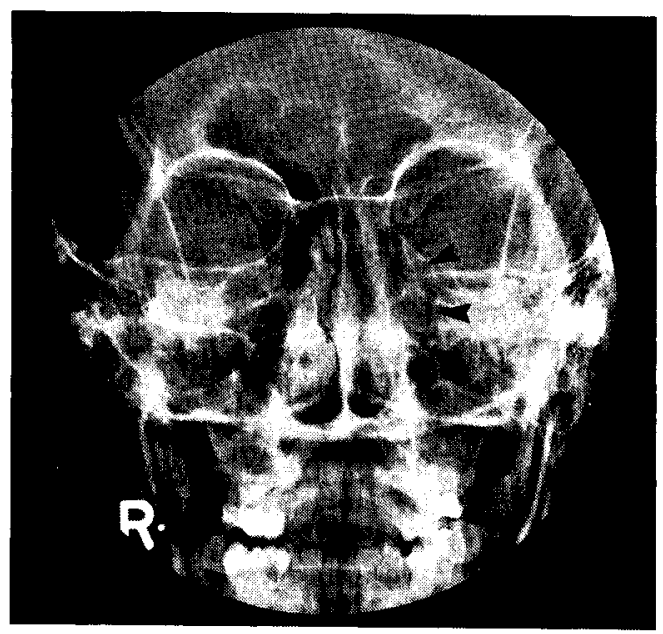

図 2 単純レントゲン写真像 矢印は腫瘤様陰影を示す

腫瘤表面はポリープ様粘膜で覆われており，鈍的 に鉗除したところ，充実性黄白色の腫瘤が充満し ていた。腫瘤摘出後, 後篩骨蜂巣の開口部を開放 し，粘稠な分泌物を多量に吸引した。

腫瘤は表面を被膜で覆われた一塊として摘出さ れ，長径 $3.6 \mathrm{~cm}$, 短径 $2.5 \mathrm{~cm}$ であった。(図 4)

術後標本の病理検查では, H-E 染色にて，クロ マチンが軽度上昇した紡錐形の核を持つ細胞の索 状配列が見られた（図 5)。S-100 蛋白染色陽性で あり，全体的に細胞の集束が密であるところから， Antoni type Aの神経鞘腫と確定した。

治療経過 : 術後約 1 カ月で鼻漏は著明に減少し, 



図 3 副鼻腔造影 CT 像 (左. 水平断·右·冠状断)

腫㾇は左鼻中隔・上顎洞内側を圧排している

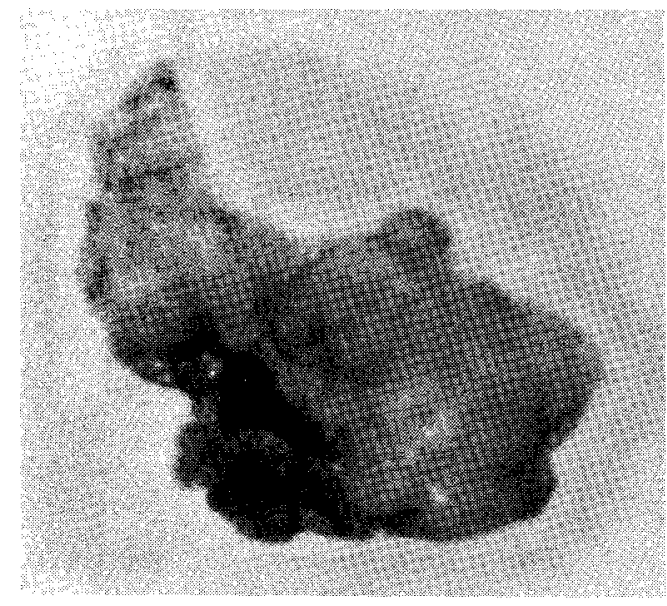

図 4 摘出標本

腫瘤は表面を被膜で覆われている。長径 $3.6 \mathrm{~cm}$, 短径 $2.5 \mathrm{~cm}$

頭痛は消失した。

平成 12 年 12 月, 術後 6 力月経過の時点で（図 6), 後部篩骨洞は解放されている。平成 15 年 10 月現在においても腫瘍の再発は認められていない。

\section{考察}

神経鞘腫は，末梢神経線維の Schwann 細胞に 由来し, 孤立性被膜を有する良性腫瘍である。頭

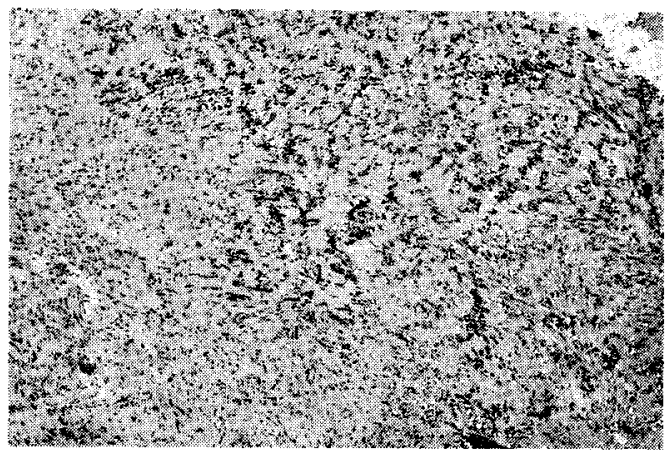

図 5 病理組織像 $(\mathrm{HE}, \times 200)$

紡鍾形の核を持つ細胞が増殖し，索状配列を呈して いる

頸部領域での好発部位としては，第四脳神経や側 頸部，副咽頭間隙が知られている。しかし，鼻・ 副鼻腔に発生するものは少なく, 頭頸部神経鞘腫 のうちでは日野原らは $11.3 \%{ }^{1)}$, Shuger らは 4 \% ${ }^{2)}$ であると報告している。また，酒井らの報告 では，鼻副鼻腔良性腫煌のうち，神経鞘腫は 0.6 \%にすぎないとしている3゙。

本邦における鼻副鼻腔神経鞘腫の報告は，犬塚 




図 6 術後 6 カ月での鼻内視鏡所見 中鼻甲介 $(\times)$ は萎縮し, 中淠道側に偏倚している *は開放された後部篩骨洞を示す

らが 1936 年から 1987 年までで 42 例 ${ }^{4}$ ，佐藤らが 1987 年から 1997 年までの 22 例であったとしてい $3^{5)}$ 。今回我々が 1997 年以降の症例を涉猟した範 囲では 12 例の報告があり，これに自験例を含め た 77 例につき文献的検討を行った。

年齢・性 : 年齢分布は 9 歳から 78 歳と幅広い。 中年, 特に 40 歳代での報告が多く 19 例であり， 平均も 47 歳である。しかし, 神経鞘腫は緩徐な 発育速度をとるため, 症状を自覚してからの受診 となることがこの年代での報告例の多い理由とも 考えられる。

性差は，国外での報告例ではほほ同率にみられ るが，本邦での報告では男性は 35 例，女性 42 例 であり (1:1.2)，女性にやや多い。

発生部位・主訴・原発神経: 発生部位は鼻腔内 が最も多く 32 例であり，次いで篩骨洞，上顎洞， 鼻中隔，蝶形洞の順に多く報告されている。田中 らが報告した篩骨洞から頭蓋底に浸潤した例 ${ }^{6)}$ ど広範囲に進展した神経鞘腫の症例も報告されて いる。

原発神経を明らかにしている症例は稀である。 鼻副鼻腔に分布する神経には，三叉神経第一枝， 第二枝，嗅神経，副交感神経末梢枝があるが，嗅 神経は無檤神経とされており，嗅神経の他の神経 は非常に細く肉眼的に確認するのは困難である。
また，術前に原発神経を推定しうる神経症状をき たす例, 術後に神経脱落症状をきたす例も極めて 稀である。このため, 術中所見などからの原発神 経の同定は一般的に困難とされている。本症例に おいては腫焬の基部が上鼻道に存在していたため, 三叉神経第二枝の枝である後篩骨神経の可能性が あると推測されたが、術中所見では腫瘍と神経と の連続性が認められなかったため，同定には至ら なかった。

初診時の主訴は腫瘍の進展範囲により異なるが, 腫瘍が鼻副鼻腔を占拠し閉塞することからの症状 が多い。すなわち, 鼻腔・鼻中隔では鼻閉, 鼻出 血, 笠骨洞では鼻閉, 視力障害, 上顎洞では鼻閉, 煩部腫脤, 眼球突出が認められている。他部位の 神経鞘腫と異なり, 原発神経の障害を疑う症状が 初発症状となることは稀であるが，これは前述の とおり，原発を疑う神経が細いためであると考え られる。自験例での主訴である頭痛は，術後ただ ちにではなく，鼻閉の改善したのちに徐々に改善 されている。これより，原発神経の障害よりも鼻 道閉塞による症状と考えられる。

画像検查: CT 検查にては, 造影にて, 辺緣が 強調され，内部が不均一な腫瘤として認められる。 このため，また，周囲の骨との関連性を明確に描 出可能である。巨大な神経鞘腫の場合、しばしば 骨の糜燗を伴う。

炎症性病変や正常組織との鑑別には, MRIの 方が CTに比して有用である。すなわち，T1 強調 画像にて中間調に強調され，T2強調画像にては， 細胞成分の多い部分では中間調となり，間質成分 の多い部分では不均一に高信号となる。これらは, ガドリニウムによる造影によって，さらに明白と なる。また，手術計画にあたり，頭蓋内，眼科内， 経動脈等への有無を確認しておくことが重要であ りこのためには前額断が有用である7゙。

自験例においては，本人が術前の MRI 施行を 拒否していた。また，CT 画像にて周囲と明瞭に 区別がつき，腫瘤の進展範囲が主に鼻腔内である と確認し得ており, 明らかな骨破壊は認められな かった。このため, 内視鏡下に充分な摘出が可能 であると考えられたため，本人の希望を尊重し MRIは施行しなかった。しかし, 前述の理由に より術前評価には有意義であるため，MRI 施行 
は望ましいと考える。

病理像: 神経鞘腫は, 肉眼的には被膜を有した 易出血性の表面平滑な腫瘍として認められる。こ のため，鼻内より観察される例の場合，一見ポリー プ様にも見える。田中らは，神経鞘腫が発育速度 が緩慢であることから，鼻腔内で長時間外気にさ らされ何らかの原因で破壊された被膜に，感染が おこり肉芽腫性変化が加われば，灰白ないし黄白 色の苔を有し，表面不整で一部に潰瘍性病変を伴 う腫瘤として認められると述べている ${ }^{6)}$ 。この 2 次性変化のため, 術前の鼻内からの生検にては神 経鞘腫と確定し得ない症例も散見する。自験例に おいても, 1 回目の生検では腫瘍と診断し得ず, 腫瘍はポリープ様粘膜に覆われていたことが術中 に確認されている。

組織像は，紡錐形の腫瘍細胞が束状あるいは渦 巻き状に集合し，且つ核が索状に配列する palisading pattern（観兵式様配列）を特徵とす る。細胞の増殖が密なものが Antoni type A, 間 質が粘液腫状となり細胞の配列が疎なものが Antoni type B と分類されている。Antoni type B は腫瘍細胞の経時変化によるとされており，両 者はしばしば混在する。また, Schwann 細胞を由 来とする腫瘍のため; S-100 蛋白による免疫染色 が陽性となることも特徵である。鑑別診断として 同じ神経原性腫瘍である神経芽細胞腫があげられ るが，被膜を持たないことより鑑別が可能である。

治療：神経鞘腫の再発は他の良性腫瘍に比べて は頻発ではないが，稀に悪性化する例があるため 手術による完全摘出を目的とする。悪性化例に術 前・術後照射を施行した症例もあるが8)，一般に は放射線に対する感受性は乏しい。術式は腫瘍の 進展範囲により決定することとなる。本邦での近 年での報告例では Denker 法, Caldwe11-Luc 法, 鼻外法，鼻内法がとられている。近年は硬性内視 鏡下の鼻内手術が一般化しているため, 術前評価
にて鼻内に限局していると確認した例であれば, 内視鏡下摘出術は有用と考える。自験例において も，術中，基部を上鼻道に確認することができ， 完全摘出が可能であった。

\section{結語}

1）左鼻腔内に生じた神経鞘腫の一例を報告し た。

2）手術は硬性内視鏡下に行い，腫瘍を完全に 摘出し得た。

3）病理組織診断の結果 Antoni type Aの神経 鞘腫であった。

4）本邦で報告された 77 例の鼻副鼻腔神経鞘腫 について検討した。

なお，本論文の要旨は，第 11 回日本頭頸部外科学会 （2001 年1月 26 日）にて口演した。

\section{参考文献}

1）日野原正，宮下賢次，吉見充徳：耳鼻咽喉科領域の 神経鞘腫について。耳展, $13: 11-17,1970$.

2) Shugar JM, Som PM, Biller HF, et al: Peripheral nerve sheath tumors of the paranasal sinus. Head and Neck Surg 4: 72-76, 1981.

3）酒井俊一：鼻・副鼻腔の腫瘍．困説臨床耳鼻咽喉科 講座 第5巻 頭頸部腫瘍・奇形 (本田芳男, 三宅 浩郷，松永透 他編)，86-89，メジカルビュ一，東 京, 1984.

4）犬塚一男, 兵 行彦, 森本孝彦, 他 : 鼻副鼻腔神経 鞘腫の一例・耳鼻臨床。補 $16: 79-86,1987$.

5）佐藤慎太郎, 高木誠治, 澤津橋基広, 他：鼻腔原発 の神経鞘腫の1例. 耳鼻と臨床, $45: 234-238,1999$.

6）田中英一, 平出文久, 井上鐵三，他：頭蓋内進展を 認めた穊骨洞神経鞘腫症例。耳鼻臨床，77：749755, 1984.

7) Berlucci M, Piazza C, Blanzuoli L, et al: Schwannoma of the nasal septum. a case report with review of the literature. Eur Arch Otorhinolaryngol $257: 402-405,2000$.

8) 藤井 守, 井口郁雄, 綾田展明, 他: 鼻腔悪性神経 鞘腫例。耳鼻臨床，93：945-949，2000. 